\title{
CLASS ACTION LITIGATION IN CHINA
}

Class struggle has moved to China's courtrooms. Since the passage of China's I99I Civil Procedure Law (CPL) ${ }^{1}$ which explicitly permits class action litigation, ${ }^{2}$ multiplaintiff groups have brought suits seeking compensation for harm caused by pollution, false advertising, contract violations, and securities law violations. Although administrative bodies continue to resolve most disputes in China, ${ }^{3}$ the increasing prevalence of class actions is one aspect of an explosion in civil litigation over the past decade. Class action litigation has the potential to alter the role courts play in adjudicating disputes, increase access to the courts, and facilitate the independence of the legal profession.

The undeveloped status of class action litigation in China, the paucity of written materials on class actions, ${ }^{4}$ the absence of statistics on its incidence, ${ }^{5}$ and the development of class actions within a legal system undergoing radical change impede any attempt to draw broad conclusions concerning the significance of class action litigation in

1 Zhonghua Renmin Gongheguo Minshi Susong Fa [Civil Procedure Law of the People's Republic of China] [hereinafter CPL], I99I ZHONGHUA RENMIN GoNGHEGUO FAGUI HUIBIAN [Collected Laws and Regulations of the People's Republic of China] 9 [hereinafter FAGUI HUIBIAN].

2 Although formally called daibiaoren susong (representative lawsuits), many Chinese commentators and press accounts use the terms jituan susong or jituanxing susong (class actions), especially when referring to suits in which the number of plaintiffs is not fixed; jituan susong is the term Chinese commentators use to describe class actions in the United States. See, e.g., Zhongguo Falï Nianjian Bianji Bu [Law Yearbook of China Editorial Department], ZHoNGGuo FALU NIANJIAN (r996) [LAW YEARBOOK OF CFINA (r9g6)] [hereinafter YEARBOOK (I996)] I26 (using the term jituanxing susong to describe group actions in China); Zhuang Shuzhen \& Dong Tianfu, Woguo Daibiaoren Susong Zhidu Yu Meiguo Jituan Susong Zhidu De Bijiao Yanjiu [Comparative Research into Our Nation's Representative Suit System and America's Class Action System], I996 Fashang YANJIU [LAW AND BusINESS REsEARCH], No. 2, at 77, 79 (using the term jituan susuong to describe class actions in the United States). This Note uses the term "class action" to describe suits brought pursuant to articles 54 and 55 of the CPL; the substance of articles 54 and 55 is discussed in Part I. However, because this Note is primarily concerned with the dynamics of multiparty litigation, and because accounts of multiparty cases often omit procedural information, "class action" may be used to refer to cases not explicitly brought pursuant to articles 54 or 55 .

3 See Tian Jiyun, Jiaqiang Fazhi Jianshe Tuidong Jingji Fazhan He Shehui Quanmian Jinbu [Strengthen Construction of the Legal System, Promote Economic Development and Comprehensive Social Progress], FazhI RIBao [Legal SySTem DaIly], Oct. 30, I995, at I, 2 (stating that administrative bodies enforce more than $80 \%$ of laws and regulations); see also Anthony R. Dicks, Compartmentalized Law and Judicial Restraint: An Inductive View of Some Jurisdictional Barriers to Reform, in CHINA's LEgAL ReForms 82, 86 (Stanley B. Lubman ed., I996) (stating that "the courts in China share the responsibility for [legislative interpretation and dispute adjudication] with other 'courts' - ministries, commissions and other bodies").

4 This Note relies upon interviews with Chinese academics, officials, and lawyers; on press accounts of multiplaintiff disputes; and on the small body of Chinese scholarship on class actions. Confidential interviews were conducted during the summers of 1996 and 1997 , and in January 1998. Interviews are identified by the year in which they were conducted and the occupation of the interviewee.

5 The Supreme People's Court does not keep statistics regarding the prevalence of class action litigation. See 1997 Academic Interview A. 
China. However, China's experience with class action legislation and litigation illuminates both its experimental approach to law reform and the evolving roles of courts, individuals, and lawyers within the Chinese legal system. As China's leaders struggle to determine whether they can foster a law-based society without losing control, class actions provide a window on fundamental tensions in the Chinese legal system: between a government policy of increasing the importance of the courts, in part to force local officials to obey the law, and a system still inhospitable to plaintiffs; between government's desire to harness a market-driven legal profession to further law implementation and its desire to continue to regulate lawyers tightly; and between government efforts to shape the legal system and the plurality of factors that contribute to the evolution of that system.

\section{STATUTORY FrameWORK}

China has one of the few legal systems outside the United States that permits class actions. ${ }^{6}$ Although a number of countries have adopted procedures by which a representative may litigate on behalf of individuals with the same interests, ${ }^{7}$ few countries other than the United States permit class actions for large or unidentified groups of plaintiffs. ${ }^{8}$ Civil law nations have often rejected class actions because such proceedings run counter to traditional views of litigation as "a matter for individual enterprise,"9 unfairly bind individuals not party to an action, and overlook traditional distinctions between public and private. ${ }^{10}$

In contrast to many nations that have rejected class actions, China has a strong collective tradition. Disputes have often been resolved collectively and informally. ${ }^{11}$ Thus, although the prevalence of class actions suggests that group disputes are increasingly being resolved through formal legal mechanisms, ${ }^{12}$ group dispute resolution itself is not

6 Cf. H. Patrick Glenn, The Dilemma of Class Action Reform, 6 OXFord J. LEgal STud. 262, 262 (1986) (noting that "class actions have been a marginal phenomenon, limited to a single judicial tradition - that of the common law").

7 See John G. Fleming, Mass Torts, 42 AM. J. CoMp. L. 507, 523 (1994). See generally Bryant G. Garth, Group Actions in Civil Procedure: Class Actions, Public Actions, Parens Patriae and Organization Actions, in GENERAL REPORTS TO THE XIITH INTERNATIONAL CONGRESS OF Comparative LAW 205, 2 I6-2 I (International Academy of Comparative Law ed., 1990) (summarizing recent developments in group actions).

8 Cf. Fleming, supra note 7 , at 520-2 I (stating that only the United States, Canada, and Australia have introduced formal class action proceedings).

9 Richard B. Cappalli \& Claudio Consolo, Class Actions for Continental Europe? A Preliminary Inquiry, 6 TEMP. INT'L \& COMP. L.J. 217, 233 (I992).

10 See id. at 223-24; Garth, supra note 7, at 207.

11 See Lester Ross, The Changing Profile of Dispute Resolution in Rural China: The Case of Zouping County, Shandong, 26 STAN. J. INT'L L. 15, I5 (1990).

12 There has been an increase in the use of a number of forms of collective action and complaints in recent years. See Lianjiang Li \& Kevin J. O'Brien, Villagers and Popular Resistance in Contemporary China, 22 MOD. CHINA 28, 28-29 (I996); Kevin J. O'Brien \& Lianjiang Li, The 
an innovation. Additionally, Chinese courts have historically been inhospitable fora for adjudicating individual rights, ${ }^{13}$ and individuals have often been reluctant to use the courts. ${ }^{14}$

China's decision to provide courts with procedures for handling group disputes appears to have been animated both by a willingness to experiment and by functional concerns regarding the ability of the judiciary to handle an increasing number of multiparty disputes. China has repeatedly experimented in law reform by selectively adapting aspects of foreign legal systems. ${ }^{15}$ In the case of class actions, China appears to have drawn heavily on the American experience. ${ }^{16}$ China's courts faced an increasing number of multiparty disputes in the late r980s, but lacked the procedures to handle them. ${ }^{17}$ The courts' difficulties stemmed from the complexity of cases involving large numbers of litigants, and from courts' own lack of resources: many judges have little or no formal legal education, ${ }^{18}$ and courts are underfunded, with their finances often controlled by the local government. ${ }^{19}$

Despite the lack of formal procedures, some Chinese courts adjudicating multiparty disputes prior to I99I used procedures resembling those later included in the CPL. ${ }^{20}$ In I985, for example, when 1569

Politics of Lodging Complaints in Rural China, CHINA Q., Sept. 1995, at 756, 756-57, 760-61, 767.

13 See Ross, supra note II, at I6-I7.

14 See Albert Hung-yee Chen, an Introduction to the Legal System of the People's Republic of China i68 (I992); see also William C. Jones, The Great QIng Code IO-II (I994) (noting that during the Qing Dynasty, legal proceedings "could be quite dreadful for everyone, including the complainant"). But see PhILIP Huang, Civil Justice IN ChINA I0-I5 (I996) (arguing that there was a significant volume of civil litigation in Qing China).

is See, e.g., Shen Zongling, Dangdai Zhongguo Jiejian Waiguo Falu De Shili (Shang) [Examples of Contemporary China's Borrowing of Foreign Law (Part I)], I997 ZHONGGUO FAXUE [CHINESE Legal Studies], No. 5, at 22, 22-28 (describing examples of China borrowing legal concepts from abroad).

16 One Chinese academic stated that Chinese academic writing on class actions in the late I980s, which drew heavily from American experience, played a role in spurring the adoption of class action procedures in the CPL. See I998 Academic Interview A. However, China apparently modeled CPL article 54 on Japanese law. See Jiang Wei \& Xiao Jianguo, Guanyu Daibiaoren Susong De Jige Wenti [Some Issues Regarding Representative Litigation], I994 FAXUEJIA [JURISTS' REVIEIW], No. 3, at 3, 3-4.

17 See Jiang Wei \& Jia Changcun, Lun Jituan Susong (Xia) [A Discussion of Class Action Litigation (Part II)], I 989 ZhoNgGuo FAXUE [CHINESE Legal STUdies], No. I, at 103, I Io; see also Zhongguo Minshi Susong Fa [ChinA's Crvil Procedure LAw] Io3 (Zhang Jinhong ed., 1996) (stating that the need for class actions stemmed from an increase in suits involving large numbers of people and from concerns over the economics of such suits).

18 See CHEN, supra note I4, at I22; Donald C. Clarke, Power and Politics in the Chinese Court System: The Enforcement of Civil Judgments, to CoLuM. J. AsIAN L. I, ro (1996).

19 See CHEN, supra note I4, at 123.

20 See Jiang \& Jia, supra note 17 , at Iro-II; Wang Hongyan, Shilun Tuixuan Daibiaoren Zhidu [An Examination of the System of Selecting Representatives], I989 FAXUE LUNCONG [Collected EsSAYS ON LEgal STUdiES], No. 2, at 34, reprinted in I989 FUYIN BAOKAN Ziliao Faxue Yuekan [Reproduced Materials from NewSPapers and Periodicals LAW MONTHLY], No. I2, at 144, 144-45. 
Sichuan farmers filed suit to enforce a seed contract, the court permitted them to select representatives to carry out the litigation. ${ }^{21}$ In addition, the Supreme People's Court (SPC) and the State Council, China's chief executive and administrative body, authorized the use of class action procedures in at least three contexts. ${ }^{22}$

China's I99I Civil Procedure Law separates class action litigation into two categories: cases in which the number of litigants is fixed, and cases in which the number is not known at the time the case is filed. Article 54 governs cases in which the number of litigants is fixed, and provides that in joint litigation ${ }^{23}$ in which the number of parties on either side of the litigation is "large," such parties may choose one or more representatives to carry out the litigation. ${ }^{24}$ The Supreme People's Court's official interpretation of the CPL defines "large" generally

The 1982 Civil Procedure Law (for Trial Implementation) permitted parties with common interests and obligations to join their actions, but did not explicitly provide for the use of class representatives. See Zhonghua Renmin Gongheguo Minshi Susong Fa (Shixing) [People's Republic of China Civil Procedure Law (for Trial Implementation)] [hereinafter CPL (for Thial Implementation)], I982 FAGUI HUIBIAN 133, arts. 47-48.

21 See Jiang \& Jia, supra note I7, at I IO-II; Wang, supra note 20, at 145 . In other cases in which the number of plaintiffs was potentially large, local authorities brought suit on behalf of the harmed parties. See, e.g., Chunyangcun Cunmin Weiyuanhui Su Huanan Jinkuangju Caijinchuan Paiwu Wuran Shuitian Sunhai Peichang Jiufen An [The Case of the Chunyang Village Villagers' Committee Suing the Huanan Gold Mining Bureau in a Dispute over Compensation for Harm to Paddy Fields Caused by Emissions from Gold Mining Boats], r988 ZHONGHUA RENMIN Gongheguo Zuigao RENMIN Fayuan Gongbao [GazeTte of THE Supreme PEOPLE'S COURT OF THE PEOPLE'S REPUBLIC OF ChINA] [hereinafter SPC GAZETTE], No. 4, at 28, 28-29 (describing a 1987 suit brought by a village committee for damages to crops from pollution). Whether governments are permitted to bring such suits today is unclear. In one case, a local government brought suit on behalf of residents suffering the effects of pollution. See Chen Tinglang, Ling Ren Kunhuo de Panjue [A Perplexing Ruling], Zhongguo Huanjing Bao [CHINA ENVIRONMENT NEwS], July 5, r997, at 3. Although the intermediate court that heard the case ordered the defendant to clean up the pollution it had caused and to pay compensation, the Heilongjiang Provincial High Court reversed the decision, stating that the local government lacked legal status to bring the case. See id.

22 See Zuigao Renmin Fayuan Guanyu Shenli Nongcun Chengbao Hetong Jiufen Anjian Ruogan Wenti De Yijian [Views of the Supreme People's Court Regarding Some Issues Related to the Judging of Village Assignment Contract Dispute Cases], I986 SPC GAzETTE, No. 3, at 3, 7 (permitting the use of representatives in cases involving large numbers of parties and stating that the actions of the representatives are binding on the represented parties); Zuigao Renmin Fayuan Guanyu Zai Shenli Jingji Hetong Jiufen Anjian Zhong Juti Shiyong Jingji Hetong Fa De Ruogan Wenti De Jieda [Response of the Supreme People's Court Regarding Some Questions Concerning the Specific Use of the Economic Contract Law in the Judging of Economic Contract Dispute Cases], I987 SPC GazeTte, No. 3, at 3, Io (same); Guoying Qiye Laodong Zhengyi Chuli Zhanxing Guiding [Provisional Regulations for the Resolution of Labor Disputes in State Enterprises], I987 FAGUI HUIBIAN 8r3, art. 4 (providing for the use of representatives in labor mediation and arbitration proceedings in which ro or more workers have common claims).

23 Article 53 defines joint litigation as litigation in which one or both sides consist of two or more parties, with such parties sharing either the same litigation objective or having claims of a similar type. See CPL, supra note I, art. 53.

24 See id. art. 54. 
to be ten or more persons. ${ }^{25}$ Additionally, it states that actions brought under articles 54 and 55 may have between two and five representatives. ${ }^{26}$

Article 55 governs cases in which the number of plaintiffs or defendants is not fixed. It provides that in cases in which many parties have similar claims, but the actual number of parties is not known at the time the case is filed, the court may issue a notice detailing the substance of the case and instructing all persons whose rights are similarly affected to register with the court within a specified period. ${ }^{27}$ The parties who register then may select one or more representatives. ${ }^{28}$

Both articles 54 and 55 provide that the actions of the representatives are binding on the represented parties. ${ }^{29}$ However, the represented parties must consent to a change in the representative or to any decision by the representative to abandon the litigation, accept a demand of the opposing party, or settle the case. ${ }^{30}$ Article 55 also provides that the court's decision is binding on all those who register with the court, and on those with similar interests who do not register but who bring suit within the prescribed litigation period. ${ }^{31}$

Aside from the few references to articles 54 and 55 in the SPC's interpretation, courts have received little guidance in handling class actions. ${ }^{32}$ Courts thus appear free to continue to experiment with class action procedures. ${ }^{33}$ In addition, although the I99I revision of the

25 See Zuigao Renmin Fayuan Guanyu Shiyong "Zhonghua Renmin Gongheguo Minshi Susongfa" Ruogan Wenti De Vijian [Interpretation of the Supreme People's Court on Questions Concerning the Implementation of the "Civil Procedure Law of the People's Republic of China"] [hereinafter SPC Interpretation], I992 SPC GAZETTE, No. 3, at 70, art. 59.

26 See id. art. 62.

27 See CPL, supra note 1 , art. 55 .

28 See id. If the parties are unable to select representatives, the court may select them after consultation with the parties. See id. The notice period must last at least thirty days. See SPC Interpretation, supra note 25 , art. 63 .

29 See CPL, supra note $\mathrm{I}$, arts. 54 \& 55.

30 See id. arts. $54 \& 55$.

31 See id. art. 55. Article 55 thus suggests that decisions are not binding on nonparticipants. However, the practical effects of this provision are unclear, as courts may be unwilling to accept a separate case on the same matter if a class action is underway. Furthermore, it may be impractical for a plaintiff to wait to bring suit until the end of the class action because the litigation period, generally two years, is likely to expire before the class action is resolved.

32 Cf. Helena Kolenda, Jerome A. Cohen \& Michael R. March, People's Republic of China, in I EnCyClopedia of International Commercial Litigation China I, China 30 (Anthony Colman ed., I996) ("The procedure when one or more joined parties do not consent to action by the representative where consent is required [is] left unaddressed and presumably subject to the court's discretion."); Minshi Susong FA JI PEITAO GuIDING XINSHI XINJIE [New Explanations of the Crvil Procedure LAW and ACCOMpanying Regulations] i63 (Liang Shuwen, Hui Huming \& Yang Rongxin eds., I996) (stating that the CPL does not specify the procedures to be followed in class actions, but that the basic procedures can be inferred from the legislation's spirit and the SPC Interpretation).

33 The procedural flexibility courts possess may facilitate experimentation. Chinese courts "are less rigidly regulated by detailed technical rules or by a clear conceptual demarcation between the judicial and administrative functions" than are courts in the West. CHEN, supra note 14, at II2. 
CPL produced a flurry of Chinese academic writing describing articles 54 and 55, and praising the procedures for increasing the efficiency of the judicial system ${ }^{34}$ and helping to resolve complex cases, ${ }^{35}$ there has been little academic analysis of actual cases. ${ }^{36}$

\section{Class Action Suits}

Post-I99I class actions have been notably varied in character. They range from a suit brought by thirty-four plaintiffs against a company in which they had purchased preferred shares for failure to pay dividends, ${ }^{37}$ to a suit brought by more than eighty airline passengers for damages suffered as a result of a delayed plane, ${ }^{38}$ to a suit by students against the publisher and seller of low-quality legal textbooks. ${ }^{39}$ Class actions appear to have been most common in disputes over low quality products, consumer fraud, environmental pollution, economic contracts, and local government actions.

In one high profile case, 300 Beijing consumers sued six Beijing department stores and watch wholesalers after purchasing watches marketed to celebrate the one hundredth anniversary of Mao Zedong's birth. ${ }^{40}$ Advertisements for the watches had claimed that they were manufactured with gold and diamonds, but the watches were in fact low-quality imitations. ${ }^{41}$ After accepting the case, originally brought

34 See, e.g., Feng Tao, Qiantan Jituan Susong [An Introductory Discussion of Class Action Litigation], I 992 RENMIN SIFA [PEOPLE'S JUDICATURE], No. 4, at 25, 26.

${ }_{35}$ See, e.g., Zhang Wusheng, Daibiaoren Susong Zhidu Chutan [An Initial Exploration of the System of Representative Litigation], Henan Daxue Xuebao (ShehuI Kexueban) [JourNaL OF HENAN UNIVERSITY (SOCIAL SCIENCES EDITION)], May I993, at 85, 86.

36 See 1998 Academic Interview A.

37 See Zhou Diwu Deng 34 Ren Su Hengyang Shi Feilong Gufen Youxian Gongsi An Yuanding Youxiangu Lirun Zhifu Guxi Jiufen An [The Case of 34 People Including Zhou Diwu Suing the Hengyang Municipality Feilong Limited Stock Company in a Dispute for the Payment of Stock Dividends in Accordance with the Originally Agreed Rate of Interest for Preferred Shares], I994 Renmin Fayuan ANLI XUAN [SElected CaSes from the PeOple's Courts], No. I, at rIo, Iro-Ir. The court ruled for the plaintiffs, ordering interest to be paid in accordance with the original notice of public offering. See id. at $112-13$.

38 See Yuan Jiang, Er Liishi "Shuaituan" Zhuanggao Hangkong Gongsi [Two Lawyers "Command a Group" in Suit Against Airline], 994 ZHONGGUo LUSHI [CHINESE LAWYER], No. 4, at 30.

39 See Liu Linshan \& Wang Xin, Falii Jiaocai Zhiliang Dilie Wuren Zidi: Tianjin Qishiming Xuesheng Shang Gongtang [Poor Quality Legal Teaching Materials Lead the Younger Generation Astray: Seventy Tianjin Students Go to Court], FazH Ribao [Legal SySTEM DaILY], Jan. 27, Ig96, at 2.

40 See Li Zhiping \& Zhong Yinli, Fengxian Haishi Qizha: Jinian Mao Zedong Zuanshi Jinbico Fengbo Jishi [An Offering of Respect or Fraud: A Record of the Storm Over Diamond and Gold Mao Zedong Commemorative Watches], Zhongguo Jing yingBao [ChInA Management NewS], July 5, 1994, at 3; 1996 Academic Interview S.

41 See Li \& Zhong, supra note 40; Li Zhiping, "Man Tianxing" Shifo Yiran Cuican? "Jinian Mao Zedong Zuanshi Jinbiao" An Shimo [Is a "Sky Full of Stars" Still Resplendent? From Start to Finish in the Case of the Mao Zedong Commemorative Diamond and Gold Watches], ZhoNGguo XIAOFEIZHE BAo [ChINA CONSUMER NEWS], Jan. 3, I996, at 2. 
by twenty-six plaintiffs, ${ }^{42}$ the Beijing Xuanwu District Court published an advertisement in the Beijing Evening News instructing all those who had purchased the watches and wished to participate in the litigation to register with the court. ${ }^{43}$ At the conclusion of the trial, the court ordered the defendants to accept the return of the watches and refund the purchase price, to pay damages of 2700 to 3000 yuan ${ }^{44}$ for each watch, and to pay fees and costs associated with the litigation. ${ }^{45}$

Peasants have brought numerous class actions for damages suffered from low quality fertilizers and seeds. ${ }^{46}$ In Sichuan, for example, 6 I $_{32}$ peasant households sued four defendants, including the seller and manufacturer of substandard fertilizer, for 2.3 million yuan after the fertilizer destroyed cotton crops. ${ }^{47}$ Class actions arising from contractual and financial disputes include a successful suit by 146 peasants against a livestock company for reneging on a contract to pay the peasants to raise martens, ${ }^{48}$ a suit for back pay, ${ }^{49}$ and suits over the supply of natural gas to individual households. ${ }^{50}$

42 See 1996 Academic Interview S.

43 See Beijing Shi Xuanwu Qu Renmin Fayuan Minshi Panjueshu Xuanmin Chuzi Di g8o Hao [Civil Decision of People's Court of Xuanwu District, Beijing Municipality, Decision No. 980], at 3-4 (I994) [hereinafter Xuanwu Civil Decision 980].

44 At current exchange rates one U.S. dollar $=8.2789$ yuan. See Prices and Trends, FAR E. ECON. REv., Mar. I2, 1998, at 58.

45 See Xuanwu Civil Decision 980, supra note 43 , at 6 . The original price of each watch was 7800 yuan for women's watches and 8800 yuan for men's watches. See id. at 3 . The six defendants appealed the decision; the appeal is pending before the Beijing Intermediate People's Court. See I997 Academic Interview B.

46 See, e.g., Chen Gang \& Huang Xianan, Fuyang Jin Liangqian Hu Nongmin Taohui Gongdao [Nearly 2000 Peasant Households in Fuyang Receive Justice], FazHI Ribao [Legal SySTem DAILY], Feb. 20, I996, at II (reporting that I994 farmers won more than two million yuan in a suit against the sellers of fake seeds); Lu Fengshan, Kaiyuan Fayuan Shenjie Nongmin Jituan Susong An [Kaiyuan Court Resolves a Peasant Class Action Case], FAzmi Ribao [Legal System DAILY], Apr. I8, I996, at 3 (reporting that 215 farmers won 90,000 yuan in a suit against a fertilizer factory).

${ }^{47}$ See Zhou Dewei, Zhongjiang Fayuan Wei Liuqian Miannong Zhui Peichang [Zhongjiang Court Seeks Compensation for Six Thousand Cotton Growers], Fazhi Ribao [LEGal SySTem DAIIY], Jan. I6, I995, at 3. The court awarded the plaintiffs damages of 1.8 million yuan plus litigation expenses. See id.

48 See Zhang Dong \& Wu Xibin, Yiqi Jituan Susongan De Chenggong Daili [Successful Representation in a Class Action], I995 ZHONGGUO LUSHI [CHINESE LAWYER], No. 6, at 4.

49 See Chen Baiqing, Renmin Fayuan Xianweili Wu Nian Jiufen San Ri Jie: 20 Ming Zhigong Shang Gongtang Taohui Gong Dao [People's Court Shows its Power by Resolving Five-Year Dispute in Three Days: 20 Workers Go to Court to Obtain Justice], Fazfir Rrbao [LEgaL SysTeM DAILY], May 15, 1995, at 3 (reporting that 20 workers successfully sued their former employer for back pay).

50 See Chongqing Xiaofeizhe Su Yehuaqi Gongying Zhan Weiyue An [Chongqing Consumers Sue the Liquefied Gas Supply Station for Breach of Contract], in SHENGCHAN JINGYING Xiaofeizhe Quanyi FalU BaOHu ANLI JingXI [ANalysis of Cases Relating to the Legal Protection of Rights of Producers, Managers, and Consumers] [hereinafter Rrghts of Producers, MANAGers, AND Consumers] 386 (Yang Li \& Liu Yanling eds., 1996); Hefei Shi Xiaofeizhe Su Yehuaqi Gongsi Weiyue An [Hefei Municipality Consumers Sue the Liquefied Gas Company for Breach of Contract], in Rights of Producers, Managers, AND CONSUMERS, supra, at 387 . 
Environmental class actions have included claims for harm suffered from air, ${ }^{51}$ noise, ${ }^{52}$ and water ${ }^{53}$ pollution. In Liu Shiyou v. Xuzhou Fangting Liquor Factory, ${ }^{54}$ eight village households brought suit against four companies that polluted the local river, killing thousands of ducks and fish that were the villagers' primary source of income. ${ }^{5 s}$ The villagers won more than 700,000 yuan in damages. ${ }^{56}$

China's Administrative Litigation Law, ${ }^{57}$ which provides for suits challenging government action, does not explicitly permit class actions. ${ }^{58}$ Nevertheless, plaintiffs have brought numerous administrative class actions, apparently borrowing the procedural framework of the Civil Procedure Law. ${ }^{59}$ In Sichuan, for example, thirty-two house-

51 See Huang Jingde \& Xiao Chengchi, Taihe Xian Liushiyi Hu Nongmin Suzhu Falil Huode Peichang [Sixty-one Peasant Households in Taihe County Win Compensation by Bringing Suit], FAZHI RIBAO [LEGAL SySTEM DAILY], Oct. 3I, I996, at 6 (reporting the settlement of a suit by 6I peasant households against brick factories for damage to their crops caused by air pollution).

52 See Cao Dengrun, Lüse de Nahan [A Green Cry], Fazhi Ribao [Legal System Daily], July I8, I996, at 3 (reporting a successful suit by 39 households against a neighboring hotel); Liu Shaoren, Fanrong Xia De Yinying - Beijing Fuwai Dajie Sihao Lou Jumin Jituan Su Fuxing Shangyecheng Jishi [In the Shadow of Prosperity - A Record of the Class Suit by Residents of Building Number Four of Beijing's Fuwai Street Against the Fuxing Shopping Center], Zhongguo HuANJING BaO [ChINA ENVIRONMENT NEWS], July I, I995, at 3 (detailing a suit by 404 residents of an apartment building against a department store for noise pollution).

53 See Zhang Peixue \& Fang Zhigang, Hegang Wuran An Fasheng Zhihou [Aftermath of the Hegang Pollution Case], Zhongguo Huanjing Bao [China Environment News], Oct. 26, I996, at 3 (reporting a successful suit by 733 households against a polluting factory).

54 Peizhou Shi Renmin Fayuan Minshi Panjue Shu Peimin Chuzi Di 1317 Hao [Civil Decision of the People's Court of Peizhou Municipality, Decision No. 1317] (1994) [hereinafter Peizhou Civil Decision I3I7].

55 See Lin Yu, Shuihuan Mengyu Hu: Fangtingheshui Wuran An Jiutuo Bujue Baixing Shenshou Qiku [A Water Disaster More Fierce than a Tiger: Hundreds Suffer Deeply from Negative Consequences as the Fangting River Pollution Case is Delayed and Not Resolved], ZHoNgGuo Huanjing Bao [CHIna ENVIRonment News], May ix, I996, at 3.

56 See Bai Yu, Fangtinghe Shuivuran An Yishen Yuangao Shengsu [Plaintiffs Win Initial Judgment in Fangting River Pollution Case], Zhongguo HUANJING BaO [ChINA ENVIRONMENT NEWS], June I, 1996, at 3. The case combined two separate actions, one class action brought by people whose fish died as a result of the pollution, and another action brought by two farmers whose ducks were killed by the pollution. See Peizhou Civil Decision 1317, supra note 54, at I-2; Peizhou Shi Renmin Fayuan Minshi Panjue Shu Peimin Chuzi Di 1318 Hao [Civil Decision of the People's Court of Peizhou Municipality, Decision No. I318], at I (1994). An appeal is pending before the Xuzhou Intermediate People's Court. See I998 Academic Interview A.

57 Zhonghua Renmin Gongheguo Xingzheng Susong Fa [People's Republic of China Administrative Litigation Law], I989 FAGUI HUIBIAN I.

58 Article 26 of the law does, however, permit joint suits, and article 27 permits third parties to join an action by applying voluntarily or after being notified by the court. See id. arts. 26-27.

59 See, e.g., Wang Wei, Wuqian Cunmin Zhuanggao Huanbaoju: Jianhu Xian Youji Huagongchang Wuran Huanjing Jiufen Caifang $J i$ [Five Thousand Villagers Sue Environmental Protection Bureau: A Record of Investigation into the Dispute over Pollution from the Jianhu County Organic Chemical Factory], Zhongguo HuANJING BaO [ChINA ENVIRONMENT News], July 22, 1995, at 3 (reporting a suit by 5000 peasants against a local environmental protection department for failure to take action against a polluting chemical factory); Xiang Peng, Tian Cai \& Qi Feng, Shouli Jihua Shengyu Jituan Susong An Shenjie: 143 Nongmin Zhuanggao Xiang Zhengfu Zhongshen Shengsu [The First Family Planning Class Action is Decided: 143 Peasants Win a Final Judgment in a Suit Against Township Govemment], FAzHI RIBAO [LEGAL SySTEM DAILX], 
holds sued the local township government for imposing excessive fees on villagers. ${ }^{60}$ The court followed the CPL provisions governing class actions, allowing the households to select two representatives. ${ }^{61}$

\section{Litigation as Policy: Structural Tensions}

The apparent rise in the number of class actions in China and the diversity of their subject matter illustrate a larger trend toward increased use of the courts to resolve disputes. China's courts heard approximately $16 \%$ more cases in 1996 than in $1995,{ }^{62}$ continuing an expansion that began in the $1980 .^{63}$ This increase stems in part from a dramatic increase in disputes, particularly economic disputes, in reform-era China, ${ }^{64}$ but also from a government policy of enhancing the importance of the courts and, consequently, litigation. 65 Litigation has grown at a much faster rate than mediation, ${ }^{66}$ and traditional govern-

Feb. 13,1995 , at 3 (describing a suit against the local township government by 143 peasants protesting a fine for an alleged violation of family planning policies); $c f$. Xing Hongfei \& Li Xiangyang, Xingzheng Susongzhong De Falü Zhangai Jiqi Duice Yanjiu [Research into Legal Impediments in Administrative Suits and Measures for Countering Them], I994 NANJING DAXUE Xuebao (Zhexue, Renwen, Shehut Kexue) [Journal of Nanjing University (Prmlosophy, Humanities, AND Social Sciences)], No. 2, at I29, r3o (noting that the Supreme People's Court has stated that in cases for which the Administrative Litigation Law does not include relevant provisions, courts may follow the CPL, and arguing that administrative class actions are essential to correct administrative errors and to prevent abuses of power).

60 See Li Shian Deng 32 Hu Nongmin Bufu Gaobanzhen Renmin Zhengfu Weifa Yaoqiu Lïxing Yiwe An $[32$ Peasant Households Including Li Shian Bring Case Against the Gaoban Township People's Government for Illegally Requiring the Carrying out of Responsibilities], 1994 Renmin Fayuan Anli Xuan [Selected Cases from the People's Courts], No. 3, at i93, I93.

61 See id. The court ruled for the plaintiffs, ordering the local government to return fees it had collected and enjoining the future collection of such fees. See id. at I94-95.

62 See Ren Jianxin, Zuigao Renmin Fayuan Gongzuo Baogao [Supreme People's Court Work Report], 1997 SPC GAZETTE, No. 2, at 55, 55. Between I991 and 1995, the number of economic cases increased by an average of $22.57 \%$ a year. See China's Supreme People's Court Work Report, BBC SUMmaRY OF WORLD BROADCASTS, Apr. 9, I996, at 3.

63 See Edward J. Epstein, Lare and Legitimation in Post-Mao China, in DoMestic Law REFoRMS IN Post-MAo CHINA 19, 38 (Pitman B. Potter ed., 1994) (stating that the number of civil cases doubled and the number of economic cases quadrupled between I 982 and I99I).

64 Cf. YEARBOOK (1996), supra note 2, at 124-25 (noting a rise in economic cases stemming from the increased complexity of economic relations and the widening scope of cases handled by courts).

65 See CHEN, supra note I4, at II5-17; Fu Hualing, Understanding People's Mediation in Post-Mao China, 6 J. CHINESE L. 2 II, 2 I7 (1992) (discussing government efforts to direct disputes to the courts).

66 Between I9go and 1994, the total number of cases heard in courts of first instance increased from 2,916,774 to 3,955,475. See Zhongguo Falï Nianjian Bianji Bu [Law Yearbook of China Editorial Department], Zhongguo FalU NianJIAN (I99I) [LAW YearbooK of ChINA (I99I)] 933 (199I) [hereinafter YEARBOOK (I99I)]; Zhongguo Falü Nianjian Bianji Bu [Law Yearbook of China Editorial Department], Zhongguo FalU NianJIAN (I995) [LAW Yearbook OF CHINA (I995)] [hereinafter YEARBOOK (I995)] I063. During the same period, the number of disputes resolved through people's mediation committees declined from $7,409,222$ to $6,123,729$. See YEARBOOK (I99I), supra, at 956; YEARBOOK (I995), supra, at ro8r. Similarly, the percentage of 
ment disdain for litigation has declined. ${ }^{67}$ Class actions may further encourage the use of the courts. ${ }^{68}$ The prospect of group action through class suits should reduce the traditional reluctance of individuals to use the courts, particularly in cases in which the defendant is a government department or enterprise or possesses significant economic clout. ${ }^{69}$ Additionally, class actions may make litigation more economically feasible by allowing plaintiffs to pool their resources to hire counsel and cover litigation costs.

The precise reasons for the apparent official encouragement of litigation are unclear. Changing economic and social relationships mean that disputes increasingly involve parties who are at arm's length; mediation may be less effective in such circumstances. ${ }^{70}$ Governmentsponsored mediation may also be less effective in a society in which state control over individuals continues to decrease. Yet class actions also illustrate that increasing the role of courts in dispute resolution may grant the government a measure of control over disputes. For ex-

civil cases brought in the courts that were resolved through court-supervised mediation decreased from $65 \%$ in 1990 to $58 \%$ in 1994. See YEARBOOK (1991), supra, at 934; YEARBOOK (1995), supra, at 1064 .

Comparing litigation and mediation rates is difficult, in part because mediation may occur in a range of settings. Cf. Donald C. Clarke, Dispute Resolution in China, 5 J. CHINESE L. 245, 256$57,270-86$ (I99) (discussing various settings in which mediation is conducted).

67 One manifestation of this shift is the CPL itself. Whereas the 1982 Civil Procedure Law (for Trial Implementation) stated that courts should emphasize mediation, see CPL (for Trial Implementation), supra note 20 , art. 6 , the $199 \mathrm{I}$ CPL provides for courts to conduct mediation on a voluntary basis, see CPL, supra note I, art. 9. Official policy in the early years of the People's Republic explicitly discouraged any form of adjudication. See Jerome Alan Cohen, Chinese Mediation on the Eve of Modernization, 54 CAL. L. REV. I201, 1201 (1966).

68 Despite increased litigation rates, there is little evidence concerning whether individuals are increasingly bringing suit in courts instead of, or in addition to, bringing their grievances to the relevant administrative authorities. Chinese academics comment that most people with grievances do not distinguish between courts and other government actors. See 1998 Academic Interview A; I 996 Academic Interview Y. Evidence from class actions suggests that, although disputes are increasingly likely to be brought to the courts, there are no clear trends regarding whether such cases are brought in addition to, after, or in place of the filing of complaints with administrative departments. In many class actions, plaintiffs appear to resort to the courts only after complaints to the relevant administrative authorities fail. See, e.g., Lan Meng, Fating Xuanpan: Huan Nongmin Baiwan "Baitiao" [Court Rules: Return Peasants' Million in "White Notes"], 1995 MINZHU YU FAZHI [DEMOCRACY AND THE LEGAL SYSTEM], No. 5, at I6, I6-17 (describing a suit brought after the local government failed to respond to plaintiffs' demands). In other cases, plaintiffs appear to pursue a dual-edged attack, using the courts and the administrative system concurrently. See, e.g., $\mathrm{Li}$, supra note 4 I (reporting that plaintiffs both complained to the government quality control association and filed suit). In still other cases, however, plaintiffs have filed suit without attempting to resolve their cases through administrative authorities, see, e.g., Yuan, supra note 38 (describing a suit filed without first complaining to the relevant administrative authority), or have been advised by administrative organs to sue, see 1996 Academic Interview $\mathrm{Y}$.

69 For example, labor law experts state that in many cases in which workers bring successful complaints against their employers, the employers later punish the workers. See r 996 Academic Interview L; 1996 Lawyer Interview B. Group litigation may lessen the risk of such reprisals.

70 See Ross, supra note II, at 64. 
ample, commentators have praised the ability of class actions to resolve disputes that might otherwise lead to social unrest. ${ }^{71}$

Class actions also demonstrate that increased dispute resolution in China's courts may facilitate other government policies. The numerous class actions brought by peasants against local officials or local economic interests have coincided with a government campaign to lessen burdens on peasants. ${ }^{72}$ Consumer class actions have appeared against the backdrop of a government effort to strengthen consumer rights and crack down on fraudulent products. Environmental class actions are consistent with government efforts to strengthen environmental protection. Although class actions often involve clashes with local policies, many class action plaintiffs are actually trying to force local authorities to follow national laws.

Yet functional weaknesses in the courts undermine the effectiveness of government efforts to enhance the importance of litigation and the courts. Such weaknesses are particularly evident in class actions, which, although designed to improve judicial efficiency, suffer from the limited competence and capacity of the courts. ${ }^{73}$ Already suffering from a lack of resources, courts are required to assume new tasks: they must notify prospective class members, supervise the appointment of class representatives, and if plaintiffs are successful, oversee the distribution of awards to large numbers of individuals. As a result, many judges resist accepting class actions out of fear that the cases will be too complex. ${ }^{74}$ Moreover, judges are often evaluated based on the number of cases they process, and thus are sometimes unwilling to take on a class action. ${ }^{75}$

Class actions also demonstrate that increasing the role courts play in resolving disputes also requires addressing disincentives to litigate. Chinese observers note that individuals are reluctant to assume risks associated with bringing a class action when the benefits of the action

71 See, e.g., Zhang \& Wu, supra note 48 , at 5 (stating that one case was a success in part because it resolved a dispute involving more than roo people, with no detriment to social stability). Many disputes do appear to result in violence. See, e.g., Wang, supra note 59 (reporting that villagers attacked a polluting factory and forced it to shut down); $\mathrm{Ci} A n$ Ruhe Liaoduan? [How Can This Case Be Decided?], Zhongguo Huanjing Bao [China Environment News], Oct. 26, 1993, at 3 (describing a similar incident).

72 Cf. O'Brien \& $\mathrm{Li}$, supra note 12 , at 764 ("The Chinese government, in reforming itself, has begun to give villagers more protection against cadre retaliation and more laws ... to point to when filing charges.").

73 Commentators note that other problems that plague the courts, notably local protectionism and corruption, are particularly acute in class actions, perhaps because such cases often involve large sums of money. See Lin, supra note 55; 1996 Academic Interview V.

74 See I 996 Academic Interview CC.

75 See 1996 Academic Interview CC; I996 Judge Interview A; I996 Lawyer Interview C. In some cases judges have refused to accept class actions, forcing plaintiffs to bring multiple similar individual actions. See Ig96 Academic Interview CC; I 996 Judge Interview A; I9g6 Lawyer Interview $C$. In others, judges have accepted class actions on the condition that they be permitted to count such actions as multiple cases. See Ig96 Lawyer Interview H. 
will accrue to others, ${ }^{76}$ and state that it is often difficult to organize affected individuals into a class. ${ }^{77}$ When the defendant is a powerful local interest or is linked to the local government, individuals may fear retaliation, particularly against the class representative. ${ }^{78}$

Court fees also discourage class actions. In most civil cases, plaintiffs must pay a filing fee, which is set according to the amount in dispute. $^{79}$ CPL article 107 permits courts to reduce or waive these fees when the courts deem it appropriate, ${ }^{80}$ and the Supreme People's Court has stated that in class actions brought pursuant to CPL article 55 , court fees shall be paid by the losing party. ${ }^{81}$ Despite these provisions, lawyers who have litigated class actions say that they are wary of not paying the fees in advance because courts rely heavily on such fees; lawyers fear requests for waivers will bias judges against their clients. ${ }^{82}$ Although in theory each class member is responsible for paying her share of court fees if the suit is unsuccessful, in practice the fee requirement discourages individuals from serving as class representatives for fear that they will be forced to pay all of the litigation fees if the class loses. ${ }^{83}$ Court fees may also discourage cases in which each individual claim is small. ${ }^{84}$ Additionally, representatives may incur a variety of other costs, including attorneys' fees, travel expenses, and costs associated with preparing evidence. ${ }^{85}$ Moreover, the time and energy required of class representatives dissuades individuals from serving as representatives. ${ }^{86}$

76 See 1996 Academic Interview CC; 1996 Lawyer Interview H.

77 See I996 Academic Interview CC.

78 See, e.g., Lan, supra note 68 , at 18 (describing efforts by family members of class representatives to dissuade them from serving as representatives in a suit against the local government).

79 See CPL, supra note I, art. I07; Zuigao Renmin Fayuan [Supreme People's Court], Renmin Fayuan Susong Shoufei Banfa [Provisions for the Collection of Litigation Fees by People's Courts], July 12, I989, in 2 Zhonghua RENMIN Gongheguo FalU Fagur Quanshu [Complete LawS AND Regulations OF the PEOPLE'S RePUBlic OF ChiNa] 1329 (1994), art. 5 (establishing a sliding fee schedule according to the amount in controversy).

80 See CPL, supra note I, art. I07.

81 See SPC Interpretation, supra note 25, art. 129.

82 See I9g6 Academic Interview CC; 1996 Lawyer Interview H; $c f$. Liu Qiaofa, Minshi Shenpan Zhong Qing Chengxu De Xianxiang, Yuanyin Jiqi Jiuzheng [Causes of and Solutions to the Phenomenon of Deemphasizing Procedure in Civil Adjudication], 1995 XIANDAI Faxue [MODERN LEgal STUdies], No. 5, at 66, 67 (noting that courts often are short of funds to cover their own operational costs).

83 See I9g6 Academic Interview V.

84 See Yang Qinwei, Tan Xiaofeizhe Quanyi Zhengyizhong De Jituan Susong Wenti [A Discussion of Issues Relating to Class Actions in Consumer Rights Disputes], I995 JingJI FAZHI [ECONOMIC LEGAL SYSTEM], No. 9, at 34, 36 .

85 Cf. Lan, supra note 68 , at I8 (stating that class representatives incurred 5000 yuan in costs in the course of the case).

86 See Gui Rong \& Xiong Zhiqiang, Lüdi Yinfa De Guansi [A Case Arising from Green Land], Zhongguo HuANJING Bao [China ENVIRONMENT News], Apr. 28, I996, at I; I9g6 Academic Interview V; z9g6 Lawyer Interview $\mathrm{H}$. 
Even when class action cases are brought, there are impediments to others joining the class. It is often difficult for class members to monitor the activities of their representatives. ${ }^{87}$ Judges in some cases exacerbate such problems by not permitting plaintiffs to select their own representatives, instead assigning local officials to represent the class, even when such officials' interests clash with those of the people they are representing. ${ }^{88}$ Further, affected individuals may not find out about actions that concern them. ${ }^{89}$ Moreover, the ability of individuals who do not participate in the class action to reap the benefits of a successful verdict produces free riders, discouraging individuals from participating in collective suits. ${ }^{90}$

The wide range of cases discussed in Part II indicates that individuals are willing to bring class actions despite multiple impediments. Nevertheless, the numerous difficulties plaintiffs confront in class suits demonstrate that the existence of class action procedures alone may not be sufficient to increase access to the courts dramatically. Tension between the government policy of increasing the courts' role in resolving disputes and the numerous barriers to effective use of the courts may be just one manifestation of the divergence of law and reality that plagues much of Chinese law, ${ }^{91}$ but this tension may also reflect broader government ambivalence toward the potential consequences of widespread use of litigation.

87 See Jiang \& Xiao, supra note I6, at 7; Liu Lei, Guanyu Woguo Daibiaoren Susong Zhidu De Jingjixue Fenxi [An Economic Analysis of the Representative Action System in Our Nation], I997 FASHANG YANJIU [LAW AND BUSINESS RESEARCH], No. I, at 72, 75; Zhang, supra note 35, at 88.

\&8 See Zhang Kaiji, Jituan Susong Ruogan Wenti [Some Questions Regarding Class Action Suits], FAzHI RIBao [Legal System DaILy], June 15, 1995, at 7; see also Zhang \& Wu, supra note 48 (noting that class representatives sometimes fail to represent the interests of the class).

89 Although in some cases class actions have been publicized in popular newspapers or even on television, see $\mathrm{Li}$, supra note $4 \mathrm{I}$; Zhang \& Wu, supra note 48 , in other cases notices are published in legal newspapers or court circulars, providing little chance that potential class members will learn of the action; see I 996 Academic Interview V. But cf. Zhou Hui, Nanjing, Wubai Bashi Ren Jituan Susong [580 People in Nanjing Bring a Class Action], NANFANG ZHOUMo [SoUTHERN WEEKEND], Sept. 2, I994, at 5 (stating that $6 \mathrm{I}_{2}$ of 855 consumers affected by a class action responded to a notice in the Jiangsu Legal System News). All class actions to date appear to be local, with notification given only in the area in which the case is filed.

90 See Liu, supra note 87 , at 74 (arguing that individuals who did not register in the class action but who filed suit within the statute of limitations should have their award reduced by double the per capita litigation costs of those who registered). In one environmental class action, numerous plaintiffs refused to participate, stating that they would sue only if the class action were successful. See 1996 Lawyer Interview H; see also Lan, supra note 68, at I7 (suggesting that individuals originally unwilling to participate in class actions joined suit after it became apparent that the plaintiffs would win).

91 See Peter Howard Corne, Foreign Investment in China: The Administrative LEGAL SYSTEM I-5O (I997). 


\section{Control of Legal Development: The Legal Profession}

The rise of class actions and the increase in litigation have coincided with the rapid growth of the Chinese legal profession. Class actions are almost certain to increase incentives for lawyers to undertake difficult cases. However, the strength of such incentives will depend both on China's regulation of lawyers' fees and on the specific roles lawyers are permitted to play in class action litigation.

The number of lawyers in China has risen from 3000 lawyers in I $980^{92}$ to 100,200 in I996.93 This number is expected to reach I50,000 by the year $2000.9^{94}$ Concurrently, lawyers have become increasingly profit-driven. China first permitted lawyers to organize into nonstate law firms in 1988,95 but until the promulgation of the 1996 Lawyers Law" all lawyers remained "state legal workers."97 Lawyers are now largely free to choose their own cases, and to run their law practices as quasi-businesses.

Despite this growth, most cases in China are litigated without the assistance of counsel, ${ }^{98}$ and lawyers ostensibly remain subject to strict fee regulation. Such regulation has caused lawyers to avoid complex or difficult cases. ${ }^{99}$ Fees for legal services are fixed at low levels; for example, fees for economic cases and civil cases involving property are

92 See William P. Alford, Tasselled Loafers for Barefoot Lawyers: Transformation and Tension in the World of Chinese Legal Workers, CHrNA Q., Mar. I995, at 22, 22.

93 See More Lawyers, CHINA DAILY, Mar. 3, 1997, at 3.

94 See Randall Peerenboom, Lawyers Commitee for Human Rights, China's Struggle to Develop a Legal Profession: The New Lawyers LaW 12 (forthcoming 1998) (manuscript on file with the Harvard Law School Library). Despite the rapid increase in the number of lawyers, many are poorly trained. See id. at 12-13; Alford, supra note 92, at 31.

95 See Timothy A. Gelatt, Lawyers in China: The Past Decade and Beyond, 23 J. INT'L L. \& PoL. 751,789 (r99I). At present, $76 \%$ of law offices in China remain state-run. See Chen Yanni, Law Sector Progresses Rapidly, ChINA DaIly, Jan. 27, I997, at I.

96 Zhonghua Renmin Gongheguo Liushi $F a$ [People's Republic of China Lawyers Law] [hereinafter Lawyers Law], in I996 ZHoNghua RENan Gongheguo XIN Fagui Huibian [Collected New Laws ANd Regulations of the People's Republic Of China], No. 2, at 39. The Lawyers Law explicitly permits lawyers to form law firms as cooperatives or as partnerships. See id. arts. 17 \& 18.

97 Zhonghua Renmin Gongheguo Lüshi Zanxing Tiaoli [Interim Regulations of the People's Republic of China on Lawyers], I980 FAGuI HuIBraN 44, art. I. The Lawyers Law states that lawyers must accept supervision from the state and society, but does not term them state workers. See Lawyers Law, supra note 96, arts. 3-4. But of. PEERENBOOM, supra note 94, at 28 (noting that the Lawyers Law "still defines a lawyer as someone who provides legal services to society, as opposed to individual clients").

98 In 1995 the Supreme People's Court reported hearing 4,889,353 cases, while lawyers reported participating in just 863,574. See YEARBOOK (1996), supra note 2, at 957, 975.

99 See Chen Wuneng \& Song Yuhong, Jianli Fuhe Woguo Guoqing De Lilshi Shoufei Zhidul [Establish a System of Lawyers Fees Suitable to Our Nation's Conditions], I9g6 ZHoNGGUo Lüshi [ChINESe LawYeR], No. 3, at 40, 41; Ma Hongjun, Lun Woguo De Liishi Shoufei Zhidu [A Discussion of Our Nation's System of Lawyers Fees], I996 Faxue Pinglun [Law Review], No. 2, at 75,77 . 
capped at three percent of the amount in controversy.100 China's strict fee regulation has led to widespread disregard of the fee limits.101 Lawyers publicly state that their fees comply with the national fee standards, ${ }^{102}$ but many comment privately that few follow the standards, and that use of contingency fees is widespread. ${ }^{103}$ Commentators have argued that the fee system should be revised to authorize clients and lawyers to negotiate fees ${ }^{104}$ and to allow contingency fees. ${ }^{105}$

The effect of regulations on lawyers' fees in class actions is unclear. Press accounts have reported that plaintiffs have had difficulties affording lawyers in class actions. ${ }^{106}$ Lawyers who have represented plaintiff classes say that such cases are rarely profitable when compared to opportunities available in commercial practice. ${ }^{107}$ Yet law-

100 See Caizheng Bu, Sifa Bu \& Guojia Wujia Ju [Ministry of Finance, Ministry of Justice \& State Price Bureau], Lüshi Yewu Shoufei Biaozhun [Fee Standards for Legal Services], Feb. 15, 1990, in Zhonghua RenMan Gongheguo FalU Fenlei Zonglan: Guojla Fa Xingzheng Fa Juan [Classified Compendium of the LaWs of the PeOple's Republic of ChINA: National LAW AND ADMINISTRATIVE LAW VoluME] thereinafter COMPENDIUM] 4I4 (I994), art. 4. Although the amount may be doubled for difficult cases, see Caizheng Bu, Sifa Bu \& Guojia Wujia Ju [Ministry of Finance, Ministry of Justice \& State Price Bureau], Lüshi Yewu Shoufei Guanli Banfa [Administrative Measures on Lawyers Services Fees] [hereinafter Administrative Measures], Feb. I5, I990, in COMPENDIUM, supra, at 413, art. 8, commentators have criticized the system because the fee, even if doubled, is often small and unrelated to the amount of work required, see Chen \& Song, supra note 99, at $4 \mathrm{I} ; \mathrm{Ma}$, supra note 99 , at 76-77.

The current status of the Fee Standards is unclear. The standards were enacted pursuant to the I990 Administrative Measures on Lawyers Services Fees. See Administrative Measures, supra, art. 16. In I997, new measures replaced the 1990 Administrative Measures. The new measures state that new fee standards will be issued; however, none have been issued to date. See Guojia Jihua Weiyuan Hui \& Sifa Bu [State Planning Commission \& Ministry of Justice], Lüshi Fuwu Shoufei Guanli Zanxing Banfa [Provisional Measures on the Administration of Fees for Lawyers Services], Mar. 3, I997, arts. 4, 20. The 1997 Measures state that fees for property disputes will be calculated based on the amount in controversy, see id. art. 7 , although they instruct the Ministry of Justice to consider a range of factors in setting the fee levels, including the difficulty of the matter and the amount of time it requires, see id. art. 6.

101 See Qing Feng, Liishi Shoufei Zhidu Gaige Tantao [An Investigation into Reform of the Lawyers Fees System], I997 ZHONGGUo LU'SEI [CHINESE LAWYER], No. 7, at 42, 42 (maintaining that the I990 fee standards exist in name only, due to a failure to adjust for inflation); x 997 Lawyer Interview A (stating that lawyers often charge in excess of the permitted amount).

102 See, e.g., Zhang \& Wu, supra note 48 , at 5 .

103 For example, one Beijing lawyer remarked that contingency fees of ten percent of the amount in dispute are common. See 1997 Lawyer Interview A. Another observer stated that some Beijing lawyers are now charging contingency fees of thirty to forty percent. See I998 Academic Interview A.

104 See Qing, supra note Ior, at 42-43; Ye Gang, Lïshi Yewu Shoufei Zhidu Gaige Qianjian [A Humble Opinion on the Reform of the Lawyers Services Fee System], ZHONGGUO LUSHI BAO [CHINA LAWYER NEwS], June I, I996, at 3.

105 See Ma, supra note 99, at 76-77; Qing, supra note ror, at 43. At least one province has issued regulations expressly permitting contingency fees. See Hainan Jingji Tequ Liishi Zhiye Tiaoli Banxing [Hainan Special Economic Zone Provisions on the Legal Profession are Promulgated], Zhongguo LUShI Bao [CHINA LAWXeR NewS], Aug. 10, 1996, at r.

106 See, e.g., Gui \& Xiong, supra note 86; Lin, supra note 55 (noting that the plaintiff spent more than 20,000 yuan for lawyers and evidence, and thus ran deeply into debt).

107 See 1996 Academic Interview K. 
yers appear to be increasingly interested in class actions, ${ }^{108}$ perhaps because they derive significant economic benefits from high profile cases regardless of the small fees the cases generate, as publicity from such cases may lead to future business for the attorneys. 109

Lawyers' roles in class actions also determine their incentives to undertake such cases. Lawyers who are able to expand the size of the class, and thus the amount in controversy, will be more willing to assume complex cases. However, it is unclear to what extent lawyers can legally encourage litigation or expand plaintiff groups. Some lawyers have openly worked to expand the size of plaintiff classes; ${ }^{110}$ in other cases, such as the Mao watch case, lawyers appear to have waited for the court to issue a notice to those whose rights were potentially implicated in the action. ${ }^{111}$

The divergence between theory and practice in legal fees reflects continuing ambivalence regarding the appropriate role of lawyers in China. China appears committed to making both courts and lawyers more accessible and to bringing increasing numbers of disputes into the formal legal system, but remains uncomfortable with providing the financial incentives required to encourage lawyers to undertake complex cases. Thus, the development of class actions is important in part for the possibility that even if legal fees continue to be tightly regulated, significant financial opportunities may exist where numerous claims are combined into one action. ${ }^{112}$ Such incentives may be particularly important in labor, environmental, and consumer cases, areas currently unattractive to many Chinese lawyers. ${ }^{113}$

\footnotetext{
108 See 1996 Academic Interview S.

109 See I996 Journalist Interview A; 1997 Academic Interview B.

110 For example, after more than ten peasants contacted lawyers regarding a contract dispute, the lawyers not only wrote to 75 other potential plaintiffs whose names were listed on the disputed contract, but also wrote an article in the local newspaper regarding the litigation. See Zhang \& Wu, supra note 48 ; see also Yuan, supra note 38 (reporting that lawyers on a delayed flight organized the other passengers to sue the airline).

111 See Li \& Zhong, supra note 40.

112 Other factors, most notably the availability of large damage awards, may also increase a lawyer's willingness to assume difficult cases. The amount in controversy in economic and administrative cases has continually increased over the past decade. See YEARBOOK (1996), supra note 2, at 125, 127. In addition, courts have begun to award damages for emotional distress. See Guo Hengzhong, Haidian Fayuan Panjue Woguo Shouli Jingshen Peichang An: Huirong Shaonil Jia Guoyu Huopei ro Wan Yuan [Haidian Court Rules in Our Nation's First Emotional Distress Damages Case: Young Girl with a Burnt Face Jia Guoyu Receives 100,000 Yuan], FazHI RrbaO [LEGAL System DaILY], Mar. 22, I997, at 2. Moreover, although China in general does not permit punitive damages, the Consumer Protection Law states that sellers of fake goods or services may be required to compensate consumers an amount equal to twice the price of the goods. See Zhonghua Renmin Gongheguo Xiaofeizhe Quanyi Baohu Fa [People's Republic of China Law Regarding the Protection of Consumers' Rights and Interests], r993 FAGUI HUIBIAN 156, art. 49.

113 Lawyers comment that the complexity and unlikelihood of victory make such cases unattractive. For example, a lawyer who litigated an environmental class action in Jiangsu commented that the case not only pitted him against powerful economic interests, but also necessi-
} 
Class actions may also suggest a shifting role for lawyers as they are drawn to cases with potentially large social impacts. The increased willingness of lawyers to challenge powerful local interests suggests that increased financial incentives may accelerate the development of a more independent legal profession, as lawyers become increasingly willing to undertake cases in which they clash with local governments. However, lawyers in such cases are not always at odds with the state: they may also be acting to force local governments or industries to obey national laws. Thus, even as China's lawyers move away from their roles as state legal workers, class actions suggest that lawyers may be assuming more active positions in the project of law implementation.

The development of class actions has coincided with China's attempts to increase access to legal advice through the construction of a legal aid system. ${ }^{114}$ Government discussion of legal aid to date has focused in part on the responsibility of the legal profession to provide assistance to those who cannot afford lawyers. Lawyers in some cities are now required either to pay for legal aid programs or to handle a certain number of pro bono cases annually. ${ }^{115}$ The development of government-sponsored legal aid in China fits well with traditional views of lawyers as state agents, with the Lawyers Law's emphasis on lawyers continuing to be subject to significant regulation by the Ministry of Justice and other government bodies, and with the desire of the central government to bring disputes into the formal legal system.

Legal aid in China has rarely involved class action litigation, ${ }^{116}$ but such cases may serve as important complements to its development. ${ }^{117}$

tated teaching the local court basic concepts of environmental law. See rg96 Academic Interview K.

114 As of July I997, 48 Chinese provincial or local governments had established some form of a legal aid center. See Sifa Bu Falü Yuanzhu Zhongxin [Ministry of Justice Legal Aid Center], Gedi Falï Yuanzhu Jigou Xunsu Jianli [Local Areas Rapidly Establish Legal Aid Organizations], FALU YuANZHU Gongzuo XIAOXI [NEwS OF WORK ON LEGAL AID], June I6, 1997, at 9, I0. For an overview of legal aid in China, see generally TANSUO YOU ZHONGGUO TESE DE FALU YUANZHU ZHIDU [EXPLORING A LEgal AID System with UNIQUe ChINESE Characteristics] (Xiao Yang ed., I996); and Benjamin L. Liebman, Legal Aid in China (March 16, 1998) (unpublished manuscript, on file with the Harvard Law School Library).

115 See Sun Jibin, Shixiang Pinruouzhe De Nuoya Fangzhou-Zhongguo Falï Yuanzhu Zai Xingdong [The Noah's Ark that is Sailing to the Poor and Weak-China's Legal Aid in Action], in EXPLORING A LEgAI AID SySTEM WITH UNIQUe ChINESE CHARACTERISTICS, supra note II4, at $99,102-05$.

116 Interviews at four of China's leading legal aid centers in the summer of 1996 revealed that the centers had conducted a total of one class action. See 1996 Government Interview P; 1996 Government Interview Q; 1996 Lawyer Interview B; I996 Lawyer Interview H.

117 It is too early to tell whether class actions will become a significant focus of China's legal aid providers. The development of class actions by legal aid providers will likely depend on the degree to which non-government legal aid providers are able to operate in China. Those lawyers interested in class actions thus far have been at university-based, non-government legal aid centers; government-funded legal aid centers have largely focused on individual civil and criminal cases. See Liebman, supra note I I4, at 88-90. 
Even a well-developed legal aid system will be able to provide assistance to only a fraction of those in need of legal help. The development of class action litigation in China suggests that, given appropriate incentives, profit-seeking lawyers may be willing to take on many of the complex cases that otherwise would be brought without lawyers or would not be brought at all.

More importantly, however, the development of class action litigation suggests that a market-driven legal profession may be essential not just to increasing access to China's courts, but also to the project of law implementation. Legal aid has developed in part because it is consistent with the central government's desire to harness the legal profession to force disputes into the legal system, and thus to increase compliance with national laws. Yet the continued strict regulation of legal fees reflects China's reluctance to recognize that increased financial incentives to lawyers may serve the same goals; indeed, legal aid is also a response to the perceived excesses of a newly market-driven legal profession. The development of class actions suggests that China's ability to use the legal profession to increase law implementation may be contingent on a willingness to grant lawyers financial incentives, which in turn requires accepting a role for lawyers largely independent of local and national government control.

Friction between the government's desire to use the newly marketdriven legal profession to further law reform and its desire to continue tight regulation of lawyers reflects a larger question: to what degree can China both direct disputes into and control the evolution of the formal legal system? The class actions described in Part II are largely consistent with the political values most likely to have been responsible for China's decision to permit class actions: the desires to steer disputes into the formal legal system, to expedite redress for certain existing collective interests, and to facilitate certain policy goals. Yet China's experience with class actions also hints that class actions in China may serve to organize otherwise unconnected individuals. As lawyers increasingly seek plaintiffs, they may be organizing individuals who would not otherwise act in concert. It remains to be seen whether the creation of such new collective interests will lead lawyers and plaintiff groups to pursue goals in tension with those of the state. ${ }^{118}$

\section{Concluston}

Class actions in China differ from individual actions not only in the number of persons involved, but also in their results. Even unsuccessful cases or unenforceable decisions may have beneficial results. Many

$118 \mathrm{Cf}$. Li \& O'Brien, supra note $\mathrm{I}$, at 55 (noting that, although consistent with "the vocabulary of the regime," actions of villagers resisting local officials may create "new understandings, new commitments, and new aspirations"). 
press accounts of class actions have noted the role such cases play in raising the legal awareness of both the litigants and society. ${ }^{119}$ The filing of a suit may at times be sufficient to attract the interest of higher-level authorities, ${ }^{120}$ or simply to pressure local officials and courts. Such consequences are particularly important given the difficulties courts face in enforcing judgments ${ }^{121}$ and the power local authorities often have over local courts. ${ }^{122}$ Class actions may also force judges and other authorities to confront cases and areas of law that might otherwise be ignored. ${ }^{123}$ Thus, although class actions are part of the general growth of litigation, they may also be more influential than other forms of litigation. Yet it is unclear whether the government intends such effects or whether they are, at least in part, an outgrowth of granting new incentives for raising collective grievances.

Class actions also demonstrate that plaintiffs may increasingly be using law to pursue their own interests and to force government action. Lawyers and litigants are doing this not only by bringing lawsuits, but also by combining lawsuits with petitioning of administrative organs and appeals to the press. Such strategies appear to be successful in part because they are consistent with state approaches to law implementation. Law in the People's Republic has never been a matter solely for the courts or the bureaucracy, and lawyers who pursue cases through the press or who file suit to pressure local authorities are taking advantage of the same mechanisms the government uses to disseminate law. The ability of class action litigants to do this reflects a system in which the state's use of law to exert control and pursue specific policy goals may be best served by allowing lawyers and litigants increased incentives and flexibility. The continued development of class action litigation may reflect not only the evolution of the state's approach toward law, but also that the ways in which litigants use the legal system to pursue their own interests may be increasingly important in shaping the evolution of law in China.

\footnotetext{
119 See, e.g., Huang \& Xiao, supra note $5 \mathrm{I}$ (claiming that a class action increased understanding of environmental law); Yuan, supra note 38 (stating that the filing of a class action had an influence on people's understanding of law and on the quality of airline service).

120 See, e.g., Wang, supra note 59 (describing intervention by the governor and the provincial environmental bureau, and the closing of a polluting factory, after 4853 villagers sued the local environmental bureau).

121 See supra pp. 1533-35 (discussing implementation problems facing class actions); see also Lan, supra note 68, at 16 (questioning whether a court judgment would be ignored by the defendant, a local government).

122 For example, a lawyer who litigated an environmental class action stated that the case was resolved against the plaintiffs when the mayor intervened on behalf of the defendant industries. See 1996 Lawyer Interview H.

123 Cf. 1996 Lawyer Interview $\mathrm{H}$ (describing as a success a court's willingness to hear an environmental class action, and noting that the case was likely to increase awareness of environmental issues regardless of the outcome).
} 